\title{
STRATEGI PEMASARAN UNTUK MENINGKATKAN PENJUALAN JASA \\ PT. JALUR NUGRAHA EKAKURIR (JNE) CABANG LAMPUNG
}

\author{
Oleh: \\ Sophan Syaiful \\ Sopi Yanti \\ Jurusan Manajemen, Universitas Mitra Indonesia \\ e-Mail : rachmatandfamily@gmail.com
}

PT. Tiki Jalur Nugraha Ekakurir merupakan perusahaan pengiriman barang milik swasta yang bergerak dibidang jasa. Banyaknya penduduk yang saling mengirim barang dari tempat yang jauh membuat jasa pengiriman barang ini menjadi sangat penting. Selama proses pengiriman barang kadang tidak selalu berjalan dengan lancar, misalnya kemungkinan terjadinya bencana, baik yang berasal dari alam, perbuatan manusia maupun dari sifat barang itu sendiri.

Kata kunci : Pemasaran, penjualan, Jasa JNE. 


\section{PENDAHULUAN}

\subsection{Latar Belakang}

Perusahaan yang bergerak di bidang jasa titipan kilat di Lampung maju sangat pesat yang salah satunya adalah JNE. JNE merupakan perusahaan yang bergerak dalam bidang pengiriman dan logistic yang berkantor pusat di Jalan Imam Bonjol No.351, Langkapura, Bandar Lampung. Nama Resminya adalah Tiki Jalur Nugraha Ekakurir dan menjadi salah satu perusahaan kurir terbesar di Indonesia. H.Soeprapto Suparno bersama Johari Zein mendirikan perusahaan PT.Tiki Jalur Nugraha Ekakurir atau yang biasa dikenal dengan Tiki JNE pada tanggal 26 November 1990.

Perusahaan ini memulai kegiatannya dengan delapan karyawan dan modal 100 juta rupiah. Pusat kegiatan usahanya yaitu penanganan kegiatan kepabean,impor kiriman barang, dokumen, serta pengantarannya.

Nilai-nilai yang dianut JNE adalah jujur,adil, disiplin,tanggung jawab, kerjasama, peduli, dan visioner. Sedangkan filosofinya yaitu efektif,efisien,fleksibel,dan seimbang.

Tahun 1991 JNE memperluas jaringan internasional dengan bergabung sebagai anggota asosiasi perusahaanperusahaan kurir beberapa Negara Asia yang berpusat di Hongkong yang kemudian member kesempatan kepada JNE untuk mengembangkan sampai keseluruh dunia. Karena persaingannya di pasar domestic, JNE juga memperluas jaringan domestic.

Dengan jaringan Domestiknya Tiki dan namanya, JNE mendapatkan keuntungan persaingan dalam pasar domestic. JNE juga memperluas pelayanannya dengan logistic dan distribusi. Selama bertahun-tahun Tiki dan JNE berkembang menjadi dua perusahaan yang punya arah sendiri.Karena itu, keduanya menjadi saingan dan akhirnya
JNE menjadi perusahaan sendiri dengan manajemen diri sendiri.

JNE meluncurkan logonya sendiri pada tahun 2000 dan berpisah dari Tiki, JNE lalu berusaha melakukan inovasi dengan memberikan layanan yang berbeda dengan TIKI. Kesan awal masyarakat menganggap layanan JNE lebih mahal dari yang lainnya. Ini karena segmen yang dibidik memang segmen premium. Pengembangan produk dan layanan yang berbeda di JNE antara lain menyediakan jasa kurir, logistic, money remittance hingga jasa kargo.

Sebagai sister company dengan TIKI, secara etika bisnis, JNE menghadapi kesulitan tidak boleh beradu harga dan layanan dengan TIKI. Namun, ternyata industry pengiriman berkembang dan pasarnya ikut membesar sehingga JNE tidak perlu merebut pasar. Perlahan-lahan JNE menemukan banyak layanan baru yang tidak yang tidak terpikir sebelumnya. JNE lalu membeli gedung pada tahun 2002 dan mendirikan JNE Operations Sorting Centers. Tahun 2004 JNE membeli gedung baru yang merupakan kantor pusat JNE dan kedua gedung ini berada di Jakarta.

Dari tahun ketahun pertumbuhan bisnis JNE pertumbuhan smakin baik, bahkan diatas rata-rata pertumbuhan industry. Industri sendiri bertumbuh hanya sebesar $10 \%$ - 15\%, namun bisnis JNE tumbuh hingga 20\% tiap tahunnya. Resep keberhasilan JNE adalah tidak mau menunggu konsumen,lebih baik JNE menjemput bola. Kurir JNE langsung menjemput barang ke rumah konsumen yang ingin mengirimkan barang. Hanya dengan menelepon, kurir pasti datang kerumah konsumen. JNE berkomitmen memberikan layanan yang terbaik. Standar JNE, kalau sampai perusahaan asuransi tidak membayar klaim sesuai hari yang ditentukan JNE bersedia menggantikan dengan membayar klaim konsumen. Bagi 
JNE barang sampai tujuan pelanggan adalah harga mati. Selain itu 170 titik jaringan sudah online sehingga ini memudahkan JNE dan pelanggan untuk mengawasi pengiriman barang.

Satu lagi layanan inovativ dari JNE yaitu pesona. Pesona adalah pesanan oleholeh Nusantara. Setiap orang bisa saling mengirimkan makanan khas daerah tertentu ke sanak keluarga di daerah lain. Contoh, mau kasih oleh-oleh kemplang $\mathrm{AB}$ ke keluarga di Jakarta anda cukup menelpon JNE dan JNE akan carikan toko oleh-oleh yang menjual kemplang $\mathrm{AB}$ tersebut dan segera mengirimkan ke alamat konsumen, bahkan es krim pun bisa dikirimkan melalui JNE. Tidak sampai disitu saja JNE banyak melakukan inovasi-inovasi unggul lainnya. JNE sekarang membuka bisnis baru yakni trucking. Ini adalah layanan pengiriman barang-barang kebutuhan pokok.

Layanan trucking ini dilengkapi dengan GPS agar terpantau. JNE juga bekerjasama dengan perusahaan pengiriman barang UPS. Konsumen bisa mengirimkan barang keluar negeri lewat UPS ini. Rencana Selanjutnya. JNE berencana terjun kebisnis surat-menyurat dibawah 50 gram. Bisnis yang sebelumnya dimonopoli PT. Pos Indonesia. Saat ini JNE berkantor pusat di Jalan Imam Bonjol No.351,Langkapura, Bandar Lampung. JNE memiliki Empat nilai dasar yang harus senantiasa diterapkan dalam beraktivitas bekerja di JNE yaitu, jujur, disiplin, Tanggung jawab, visioner.

\subsection{Rumusan Masalah dan Identifikasi Masalah}

Rumusan masalah dalam penelitian ini adalah :

Bagaimana implementasi strategi pemasaran PT. JNE agar kwalitas pelayanan lebih baik tetapi dengan harga yang terjangkau / tidak mahal ?
Identifikasi masalah dalam penelitian ini adalah :

1. Bagaimana implementasi strategi pemasaran PT. JNE agar kwalitas pelayanan lebih baik tetapi dengan harga yang terjangkau / tidak mahal ?

2. Faktor- faktor apa saja yang mendukung \& menghambat didalam strategi pemasaran JNE?

\subsection{Tujuan Penelitian}

Berdasarkan rumusan rumusan masalah diatas, maka tujuan penelitian ini adalah

1. Untuk mengetahui perkembangan seberapa jauh pelaksanaan strategi pemasaran dalam mengirim barang-barang mereka dengan menggunakan titipan JNE.

2. Untuk mengetahui sejauh mana pola pengiriman barang $\&$ jasa di PT. JNE untuk sekali pengiriman barang, dan harga untuk sekali pengiriman.

\subsection{Manfaat Penelitian}

Manfaat penelitian / kegunaan penelitian yang dilakukan penulis adalah :

1. Untuk mengetahui seberapa besar pengguna titipan kilat JNE ini

2. Untuk mengetagui kekurangan / kelebihan yang dialami oleh karyawan bagian lapangan

3. Untuk mengetahui apa yang di ingin oleh konsumen sehingga kita bisa memenuhi keinginan konsumen.

\subsection{Kerangka Pikir}

PT. Tiki Jalur Nugraha Ekakurir merupakan perusahaan pengiriman barang milik swasta yang bergerak dibidang jasa. Banyaknya penduduk yang saling mengirim barang dari tempat yang jauh membuat jasa pengiriman barang ini menjadi sangat penting. Selama proses pengiriman barang kadang tidak selalu berjalan dengan lancar, misalnya kemungkinan terjadinya bencana, 
baik yang berasal dari alam, perbuatan manusia maupun dari sifat barang itu sendiri. Rumusan masalah dalam penelitian ini adalah bagaimanakah pelaksanaan tanggung jawab JNE dalam perjanjian pengiriman barang apabila terjadi wanprestasi. Untuk itu tujuan penelitian ini adalah untuk memahami syarat dan prosedur perjanjian pengiriman barang, hak dan kewajiban para pihak serta tanggung jawab JNE bila terjadi wanprestasi. Penelitian ini adalah penelitian hukum normative terapan dengan tipe penelitian eskriptif.

Pendekatan masalah yang digunakan bersifat terapan. Data yang digunakan dalam penelitian ini adalah data sekunder dengan metode pengumpulan data yang dilakukan dengan studi pustaka, dokumen dan wawancara. Setelah data terkumpul, selanjutnya data diolah dengan cara pemeriksaan data, klasifikasi data, dan penyusunan data.

Analisis secara kualitatif Berdasarkan hasil penelitian menunjukan bahwa syarat dalam pengiriman barang yaitu dengan cara mengisi AWB (Air Waybill)/Connot, yaitu form pengisian pengiriman barang.

Air Waybill harus diisi dengan nama dan alamat yang lengkap, jelas, benar dan terbaca agar barang atau dokumen yang akan dikirim bisa sampai ke tempat yang dituju. Sedangkan prosedur dalam pengiriman barang yaitu pemeriksaan terhadap barang :

Barang yang akan dikirim Apabila barang barang tersebut layak untuk tersebut dengan mengeluarkan AWB (Air Waybill) sebagai dokumen perjanjian pengiriman barang yang ditandatangani oleh kedua belah pihak. AWB (Air Waybill) tersebut berisikan hak dan kewajiban para pihak. Kewajiban perusahaan adalah menyiapkan barang yang akan dikirim.
Mengantarkan barang / dokumen sampai ketempat yang dituju, dan melindungi barang / dokumen agar tidak rusak dan hilang. Hak perusahaan adalah berhak mendapat keterangan mengenai sifat barang yang akan dikirim, menolak permintaan pengiriman barang yang terlarang atau tidak sah dan menerima biaya yang diperlukan dalam pengiriman barang. Sedangkan kewajiban konsumen membukus barang yang akan dikirim dengan rapi, memberikan keterangan mengenai sifat barang yang akan dikirim dan membayar biaya yang diperlukan dalam pengiriman barang.

Hak konsumen adalah mendapatkan tanda bukti pengiriman, barang yang dikirim sampai tepat pada waktunya, dan konsumen berhak menuntut ganti rugi jika terjadi kehilangan atau kerusakan barang yang disebabkan oleh kesalahan atau kelalaian dari perusahaan pengiriman / JNE atau yang mewakilinya.

Yaitu dengan cara mengganti kerugian sebesar 10 kali biaya pengiriman, kecuali jika PT. Jalur Nugraha Ekakurir dapat membuktikan secara benar dan jelas bahwa kesalahan tersebut bukan kesalahan dari PT. Jalur Nugraha Ekakurir, melainkan akibat kelalaian dan kesalahan dari pihak pengirim barang atau karena terdapat keadaan memaksa yang mengakibatkan barang muatan tersebut tidak sampai di tangan pihak penerima barang, hal inilah yang membebaskan PT. Jalur Nugraha Ekakurir dari tuntutan.

Berikut ini bagan kerangka pikir dari keterangan di atas : 


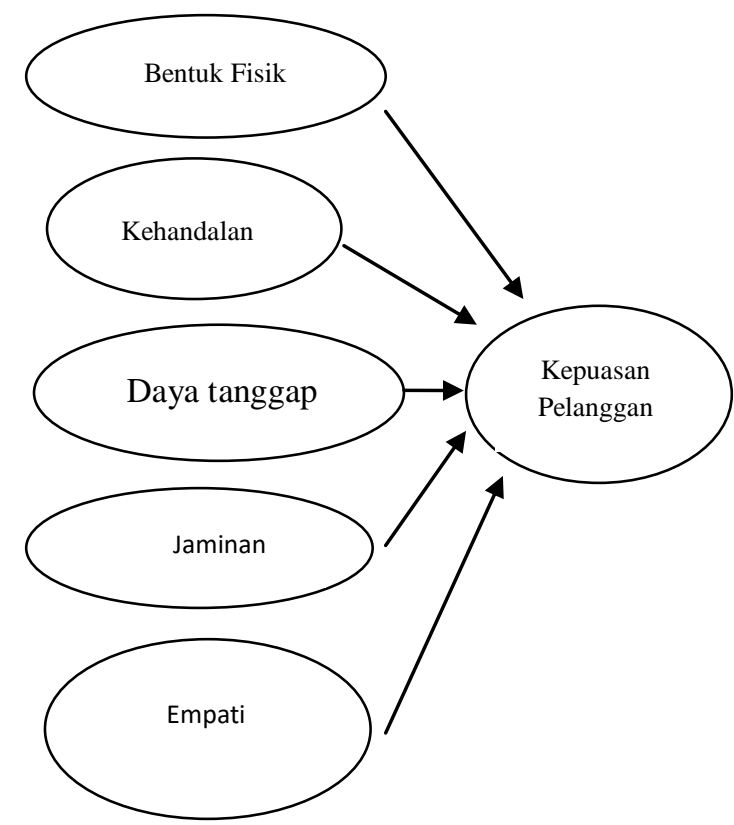

Kepuasan pelanggan dipengaruhi bukti fisik (tangible).

Kepuasan pelanggan dipengaruhi kehandalah (reliability).

Kepuasan pelanggan dipengaruhi jaminan (assurance).

Kepuasan pelanggan dipengaruhi empati (empathy).

Bukti Fisik (tangible) berpengaruh dominan terhadap kepuasan pelanggan.

\section{LANDASAN TEORI}

\subsection{Pengertian pemasaran \\ Jasa}

Perkembangan dunia bisnis pada era globalisasi menuntut kinerja yang sempurna dari setiap proses yang dijalankan oleh perusahaan. Pemasaran tidak lagi dipandang sebagai bagian yang terpisah dari organisasi yang hanya berperan sebagai penjualan produk. Perkembangan konsep pemasaran sendiri tidak terlepas dari fungsi-fungsi organisasiyang lain dan pada akhirnya mempunyai tujuan untuk memuaskan pelanggan.

Pemasaran yang tidak efektif (ineffective marketing ) dapat membahayakan bisnis karena dapat berakibat pada konsumen yang tidak puas. Pemasaran yang efektif ( effective marketing ) justru berakibat sebaliknya yaitu menciptakan nilai atau utilitas. Menciptakan nilai dan kepuasan pelanggan adalah inti pemikiran pemasaran modern.

Tujuan kegiatan pemasaran adalah menarik pelanggan baru dengan menjanjikan nilai yang tepat dan mempertahankan pelanggan saat ini dengan memenuhi harapannya sehingga dapat menciptakan tingkat kepuasan.

Menurut Lupiyoadi ( 2006;5 ), Pemasaran jasa adalah setiap tindakan yang ditawarkan oleh salah satu pihak kepada pihak lain yang secara prinsip intangible dan tidak menyebabkan perpindahan kepemilikan apapun. Sedangkan menurut Umar ( 2003;76 ), pemasaran jasa adalah pemasaran yang bersifat ingtalible dan immaterial dan dilakukan pada saat konsumen berhadapan dengan produsen.

Dari definisi diatas dapat disimpulkan bahwa pemasaran jasa adalah suatu tindakan yang ditawarkan pihak produsen kepada konsumen, dalam arti jasa yang diberikan tidak dapat dilihat, dirasa, didengar atau diraba sebelum dikonsumsi. Bauran pemasaran jasa merupakan pengembangan bauran pemasaran. Bauran pemasaran ( marketing mix ) hanya mencakup 4P yaitu :

1. Produk

2. Harga

3. Tempat

4. Promosi

Sedangkan untuk jasa keempat $\mathrm{P}$ tersebut masih kurang mencakupi, sehingga para ahli pemasaran menambahkan 3 unsur yaitu

\section{Manusia \\ 2. Proses \\ 3. Pelayanan}

Sehingga total semuanya dalam pemasaran jasa atau. bauran pemasaran jasa mencakup 7 hal. 


\subsubsection{Produk Jasa}

Menurut Kotler yang dikutif oleh Ratih Hurriyati ( 2010 : 50 ) menyatakan definisi produk jasa adalah segala sesuatu yang dapat ditawarkan produsen untuk diperhatika, diminta, dicari, dibeli, digunakan atau dikonsumsi pasar sebagai pemenuhan kebutuhan atau keinginan pasar yang bersangkutan. Untuk merencanakan penawaran pemasar perlu memahami tingkatan produk,yaitu sebagai berikut :

1. Produk utama / inti yaitu manfaat sebenarnya dibutuhkan dan akan dikonsumsi oleh pelanggan dari setiap produk.

Produk generic yaitu produk dasar yang mampu memenuhi fungsi produk yang paling dasar.

2. Produk harapan yaitu produk formal yang ditawarkan dengan berbagai atribut dan kondisinya secara normal diharapkan dan disepakati untuk dibeli.

3. Produk pelengkap yaitu sebagai atribut produk yang dilengkapiberbagai manfaat dan layanan.

4. Produk potensial yaitu segala macam tambahan dan perubahan yang mungkin dikembangkan untuk suatu produk dimasa mendatang.

Jadi pada dasarnya produk adalah sekumpulan nilai kepuasan yang kompleks. Nilai sebuah produk ditetapkan oleh pembeli berdasarkan manfaat yang akan mereka terima dari produk tersebut.

\subsubsection{Harga}

Harga adalah sejumlah uang sebagai alat tukar untuk memperoleh produk atau jasa. Ada 3 dasar untuk menetapkan harga yang biasa digunakan dalam menentukan harga yaiti

1. Penetapan harga berdasarkan biaya.

2. Penetapan harga berdasarkan persaingan.
3. Penetapan harga berdasarkan permintaan.

Menurut Djaslim ( 2002 : 107 ), pemasaran adalah terdiri dari seperangkat lembaga yang melakukan semua kegiatan yang diunakan untuk menyalurkan produk dan jasa dan status pemiliknya dari produsen ke konsumen.

\subsubsection{Tempat}

Lokasi berhubungan denga keputusan yang dibuat oleh perusahaan mengen dimana operasi dan stafnya akan ditempatkan. Yang paling penting dari lokasi adalah tipe dan tingkat interaksi yang terlihat. Terdapat 3 macam tipe interaksi antara penyedia jasa dan pelanggan yang berhubungan dengan pemilihan lokasi yaitu

1. Pelanggan mendatangi penyedia jasa

2. Penyedia jasa mendatangi pelanggan

3. Penyedia jasa dan pelanggan melakukan interaksi melalui

Pengurus

\subsubsection{Promosi}

Promosi menurut Fajar Laksana ( 2009:133 ) adalah suatu bentuk

komunikasi dari penjual dan pembeli yang berasal dari informasi yang tepat yang bertujuan untuk merubah sikap dan tingkah laku pembeli yang tadinya tidak mengenal, sehingga menjadi pembeli dan tetap mengingat produk dan jasa terebut. Sedangkan menurut Djaslim Saladin (2007:123) promosi ialah suatu komunikasi informasi penjual dan pembeli yang bertujuan untuk merubah sikap dan tingkah laku pembeli atau pelanggan yang tadinya tidak mengenal menjadi mengenal sehingga menjadi pembeli dan tetap mengingat produk dan jasa tersebut. Promosi merupakan salah satu faktor penentu 
keberhasilan suatu program pemasaran. Tujuan utama dari promosi adalah menginformasikan, mempengaruhi dan membujuk serta mengingatkan pelanggan tentang perusahaan dan bauran pemasarannya. Secara rinci ketiga tujuan promosi tersebut adalah sebagai berikut;

1. Menginformasikan (informing)

Adalah menginformasikan pasar mengenai keberadaan atau produk baru, memperkenalkan cara pemakaian dari suatu produk, menyampaikan perubahan harga kepada pasar, menjelaskan cara kerja satu produk, menginformasikan jasa-jasa yang disediakan oleh perusahaan, mengurangi ketakutan dan khawatiran pembeli dan membangun citra perusahaan.

2. Membujuk Pelanggan sasaran ( persuading )

Adalah untuk membentuk pilihan merek, mengalihkan pilhan ke merek tertentu, mengubah persepsi pelanggan terhadap atribut produk, mendorong pembeli untuk belanja saat itu juga dan mendorong pembeli untuk menerima kunjungan salesmen.

3. Mengingatkan ( Reminding )

Dapat terdiri atas mengingatkan pembeli bahwa produk yang bersangkutan dibutuhkan dalam waktu dekat, mengingatkan pembeli akan tempat-tempat yang menjual produk perusahaan, membuat pembeli tetap ingat walaupun tidak ada kampanye iklan dan menjaga agar ingatan pertama pembeli jatuh pada produk perusahaan.

\subsubsection{Manusia}

Manusia adalah semua pelaku yang memainkan peranan dalam penyajian jasa sehingga dapat mempengaruhi persepsi pembeli. Perilaku orang-orang yang terlibat langsung ini sangat penting dalam mempengaruhi mutu jasa yang ditawarkan dan image perusahaan yang bersangkutan.

\subsubsection{Proses}

Menurut Zeithalm dan Bitner yang dikutip oleh Ratih Hurriyati (2010:64) menyatakan bahwa proses adalah semua prosedur actual, mekanisme dan aliran aktivitas yang digunakan untuk menyampaikan jasa. Dalam bahasa inggrisnya adalah " The actual procedures, mechanism and flow of activities by wich the service is delivered the service delivery and operating system". Element proses ini mempunyai arti suatu upaya perusahaan dalam menjalankan dan melaksanakan aktivitasnya untuk memenuhi kebutuhan dan keinginan konsumennya. Untuk perusahaan jasa, kerjasama antara pemasaran dan operasional sangat penting dalam element proses ini, terutama dalam melayani segala kebutuhan dan keinginan konsumen. Jika dilihat dari sudut pandang terutama konsumen maka kualitas jasa dilihat dari bagaimana jasa menghasilkan fungsinya.

Proses dalam jasa merupakan factor utama dalam bauran pemasaran jasa seperti pelanggan jasa akan sering memasarkan sistem penyerahan jasa sebagai bagian dari jasa itu sendiri. Selain itu, keputusan dalam manajemen.

\subsubsection{Pelayanan}

Sarana fisik merupakan suatu hal yang secara nyata turut mempengaruhi keputusan konsumen untuk membeli dan menggunakan produk jasa yang ditawarkan. Unsur-unsur yang termasuk di dalam sarana fisik antara lain lingkungan fisik, dalam hal ini lingkungan fisik, peralatan, perlengkapan, logo, warna dan barang-barang lainny yang disatukan 
dengan service yang diberikan seperti tiket, sampul, label dan lain sebagainya.

\subsection{Karakteristik Jasa}

Berbagai riset dan literature menajemen dan pemasaran jasa mengungkapkan bahwa jasa memiliki empat karakteristik yang membedakan barang dan jasa yang dinamakan paradigma IHIP. Yaitu : Intangibility, Heterogeneity, Inseparability, dan Perishability ( Lovelock \& Gummeson, 2004 ) ( dikutip dalam Tjiptono dan Chandra, 2005;22)

1. Intangibility

Jasa bersifat itangible, artinya jasa idak dapat dilihat, dirasa, dicium, didengar, atau diraba sebelum dibeli dan dikonsumsi

2. Heterogeneity

Jasa bersifat Heterogeneity karena merupakan non-standarized output, artinya terdapat banyak fariasi bentuk,kualitas dan jenis, tergantung pada siapa, kapan dan dimana jasa tersebur diproduksi.

3. Inseparability

Jasa bersifat Inseparability artinya jasa dijual terlebih dahulu, baru kemudian diproduksi dan dikonsumsi pada waktu dan tempat yang sama.

4. Perishability

Jasa bersifat perishability artinya jasa merupakan komoditas yang tidak tahan lam, tidak dapat disimpan untuk pemakaian ulang,dijual kembali, dikembalikan.

2.3 Teori Tentang Kualitas

Pelayanan

Pelayanan adalah rasa menyenangkan atau tidak menyenangkan yang diperoleh penerima pelayanan pada saat menerima pelayanan.
Pengertian Kualitas Pelayanan. Kualitas Pelayanan adalah tingkat kesempurnaan yang diharapkan dan pengendalian atas tingkat keunggulan tersebut untuk memenuhi keinginan pelanggan.

Kepuasan pelanggan adalah evaluasi pelanggan terhadap kinerja produk / layanan yang sesuai atau melampaui harapan konsumen. Faktor-Faktor Yang Menentukan Tingkat Kepuasan., Antara lain :

Menurut Lupiyodi ( 2001 ; 159 ), terdapat 3 faktor utama yang harus diperhatikan oleh perusahaan dalam menentukan tingkat kepuasan pelanggan,yaitu : Kualitas produk \& kualitas pelayanan, sehingga Sifat-sifat khusus jasa perlu diperhatikan dan pertimbangan dalam merancang program pemasaran.

Menurut Kotler yang dikutif oleh Ratih Huriyati ( 2010 : 28 ) bahwa jasa memiliki 4 ciri utama yang sangat mempengaruhi rancangan program pemasaran yaitu :

1.Tidak Berwujud

2.Tidak Terpisahkan

3.Bervariasi

4.Mudah Musnah

Industri jasa sangat beragam, sehingga tidak mudah untuk menyamakan cara pemasarannya. Klafisikasi jasa dapat membentuk / memahami batasan-batasan dari industri jasa . Ada beberapa macam tipe klafisikasi jasa yaitu :

1.Jenis Jasa

2.Jasa Profesioal

3.Jenis Pelanggan

4. Individu

5. Jasa Lainnya

\subsection{Perbedaan antara barang dan jasa antara lain yaitu ;}

1. Pembelian jasa sangat dipengaruhi oleh motif yang didorong oleh emosi 
2. Jasa bersifat tidak berwujud, sedangkan barang berwujud, dapat dilihat, dll

3. Jasa dibeli dan dikonsumsi pada waktu yang sama sedangkan barang bersifat tahan lama

4. Jasa tidak dapat disimpan sedangkan barang dapat disimpan

\subsection{Sistem Bisnis Jasa}

Jasa merupakan suatu proses yang menyangkut input dan output.

Terdapat 4 jenis input yang dapat diproses dalam suatu jasa yaitu sebagai berikut :

1. Pemprosesan terhadap pelanggan

2 .Pemprosesan terhadap barang

3. Pemprosesan terhadap informasi

4. Pemprosesan terhadap stimulasi mental

\subsection{Pemasaran Jasa}

Inustri jasa pada saat ini merupakan sector ekonomi yang sangat besar dan pertumbuhannya pun sangat pesat. Pertumbuhan tersebut selain diakibatkan oleh pertumbuhan jenis jasa yang sudah ada sebelumnya, juga disebabkan oleh munculnya jenis jasa baru, sebagai akibat dari tuntutan dan perkembangan zaman. Dipandang dari segi konteks globalisasi, pesatnya pertumbuhan bisnis jasa antar Negara ditandai dengan meningkatnya intensitas pemasaran lintas Negara serta terjadinya aliansi sebagai penyedia jasa didunia.

Pemasaran jasa merupakan suati proses mempersepsikan, memahami, menstimulasi dan memenuhi kebutuhan pasar sasaran yang dipilih secara khusus dengan menyalurkan sumber-sumber sebuah organisasi untuk memenuhi kebutuhan tersebut.

Fungsi pemasaran terdiri dari 3 komponen kunci, yaitu sebagai berikut
1. Bauran Pemasaran
2. Kekuatan Pasar

\section{Proses penyelarasan}

Tugas dari menajer dalam menyusun program pemasaran adalah mengintegrasikan unsur-unsur bauran pemasaran agar dapat memastikan keselarasan yang terbaik antara kemampuan internal dan lingkungan pasar eksternal.

\subsection{Strategi Pemasaran}

Pemasaran dalam bahasa inggris dikenal dengan nama marketing. Memasarkan barang tidak berarti hanya menawarkan barang atau menjual, tetapi lebih dari itu. Di dalamnya tercakup berbagai kegiatan seperti membeli, menjual, dengan segala macam cara, menyangkut barang, menyimpan, mensortir dan sebagainya. Didalam marketing usaha ini kita kenal sebagai fungsi-fungsi marketing.

Jasa merupakan aktivitas atau manfaat yang ditawarkan oleh satu pihak ke pihak lainnya dan tidak mengakibatkan perpindahan kepemilikan . Jasa tidak berwujud, tidak dapat dipisahkan,berubahrubah dan tidak tahan lama. Pemasaran dalam suatu perusahaan menghasilkan kepuasan pelanggan serta kesejahteraan konsumen dalam jangka panjang sebagai kunci untuk memperoleh profit / laba. Hal ini berlaku bagi perusahaan yang bergerak dibidang industri jasa maupun industri non jasa. Walaupun terdapat persamaan tujuan pada kedua jenis industri tersebut, diperlukan strategi pemasaran yang berbeda untuk masing-masing jenis industri. Perbedaan strategi tersebut dipengaruhi oleh ciri-ciri dasar yang berbeda dari jenis produk yang dihasilkan.

Menurut Kotler yang dikutif oleh Ratih Hurriyati ( 2010 : 47 ) menyatakan bahwa definisi bauran pemasaran adalah sekumpulan alat pemasaran yang dapat digunakan oleh perusahaan untuk mencapai tujuan pemasarannya dalam pasar sasaran. 
Penambahan unsur bauran pemasaran jasa dilakukan antara lain karena jasa memiliki karakteristik yang berbeda dengan produk, yaitu tidak berwujud, tidak dapat dipisahkan, beraneka ragam dan mudah lenyap.

\section{METODE PENELITIAN}

\subsection{Jenis penelitian}

Jenis penelitian yang digunakan adalah deskriptif kualitatif. Penelitian menggunakan jenis deskriptif kualitatif karena menggambarkan karakteristik dari usaha / jasa pengiriman barang PT. Jalur Nugraha Ekakurir (JNE) cabang Lampung dan menggambarkan strategi pemasaran PT. Jalur Nugraha Ekakurir cabang Lampung, serta ingin mendekan hasil penelitian dengan menggunakan kata-kata tertulis.

Dalam penelitian ini data yang dikumpulkan tidak berbentuk angka, melainkan dalam bentuk kata, kalimat, pernyataan, dan konsep. Tujuannya adalah menggambarkan secara terperinci dan relatif akurat mengenai topik yang diangkat dalam penulisan ini. Segala kegiatan pengumpulan data diperoleh narasumber yang dipercaya dari pihak PT. Jalur Nugraha Ekakurir (JNE) cabang Lampung dan konsumen dari PT. Jalur Nugraha Ekakurir (JNE)

\subsection{Pengumpulan Data}

\section{A. Data Primer}

Data primer adalah data yang diperoleh secara langsung dari sumbernya yaitu PT. Jalur Nugeraha Ekakurir ( JNE ). Diamati dan dicatat untuk pertama kalinya oleh penulis. Data tersebut diperoleh melalui

\section{Quisioner}

Pendekatan ini dilakukan dengan memberikan daftar pertanyaan kepada key informan dan informan guna menunjang data yang berhubungan dengan penelitian.

\section{Observasi}

Observasi dilakukan pada bulan Januari sampai maret 2017, meliputi pengamatan langsung terhadap PT. Jalur Nugeraha Ekakurir apa yang dilakukan untuk memasarkan jasa mereka, baik dikantor cabang maupun di agen-agen PT.Jalur Nugeraha Ekakurir ( JNE ), yang kemudian dijadikan data tertulis sebagai rekomendasi isi penelitian ini.

\section{Wawancara}

Wawancara yang dilakukan oleh penulis sebagai hasil dari beberapa pertanyaan yang diteliti oleh penulis agar semua kriteria dapat terjawab dengan sesuai, selain melalui quisioner dan observasi yang dilakukan pada saat itu.

Didalam wawancara dengan narasumber yang telah dipilih adalah Bapak Wahid selaku kepala bagian Pelayanan dimana semua masalah pelayanan ditangani oleh beliau. Pada hakekatnya semua pertanyaan tersebut memiliki jawaban yang diharapkan sesuai dengan topik dan teori yang terpilih oleh penulis didalam membahas Strategi Pemasaran Untuk Meningkatkan Pelayanan Jasa PT.Jalur Nugraha Ekakurir (JNE). Berikut dibawah ini adalah pertanyaan yang telah diajukan kepada narasumber pada umumnya merupakan pertanyaan yang sama mengenai jati diri narasumber. Seperti hal nya berapalama Bapak/Ibu bekerja di perusahaan, kemudian pertanyaan mengenai jabatan perusahaan dan yang terakhir adalah mengenai latar belakang pendidikan narasumber. Pertanyaan yang selanjutnya yang telah diajukan kepada Bapak Wahid mengenai hal-hal yang terlibat dengan karyawan PT.Jalur Nugraha Ekakurir (JNE) juga mengenai strategi pemasarannya seperti pertanyaan beikut ini

"Strategi apa yang digunakan untuk meningkatkan pelayanan?" Bapak Wahid langsung menjawab dengan jelas seperti 
pernyataan berikut ini : "Selama ini kita melakukan promosi dan meningkatkan pelayanan sehingga konsumen senang dengan kita kan kalau konsumen senang tuh pasti mereka dating lagi ke kita"

"Pelayanan apa yang diberikan sehingga menarik konsumen lebih memilih PT.JNE untuk pengiriman barang? Padahal banyak jasa pengiriman yang lain?" Bapak Wahid langsung menjawab dengan jelas seperti pernyataan berikut ini : "Ya pelayanan kami 24 Jam dan kami bisa menjemput juga jadi kalau ada konsumen yang mau kirim barang tapi tidak ada kendaraan ya kita bisa jemput paketnya, kami juga kalau ada paket yang hilang kami mengganti paket tersebut"

Tindakan selanjutnya untuk menggabungkan antara data yang diperoleh dengan teori yang di terima penulis selama belajar maka digabungkan kembali didalam sebuah pengolahan data yang berupa serangkaian kegiatan pelayanan didalam PT.Jalur Nugraha Ekakurir (JNE).

\section{B. Data Sekunder}

Data sekunder adalah data yang didapatkan dari buku, serta materi tertulis yang relevan dengan tujuan penelitian. Data sekunder peneliti peroleh melalui pengumpulan data dari pihak PT. Jalur Nugeraha Ekakurir ( JNE ) cabang Lampung, dan melalui studi kepustakaan baik berupa dokumen maupun dokumentasi.

\subsection{Penentuan Key Informan dan Informan}

Key Informan adalah narasumber kunci atau utama yang paling banyak tahu sesuatu informasi ( data ) mengenai hal yang diteliti. Sedangkan Informen adalah seorang narasumber biasa atau anggota kelompok yang beranggota kelompok yang diriset yang diharapkan mempunyai berbagai informasi penting.
Penentuan key informen dan informan, peneliti menggunakan purposive sampling, yaitu pemilihan sample berdasarkan karakteristik tertentu yang dianggap mempunyai hubungan / sangkut paut dengan karakteristik populasi yang sudah diketahui sebelumnya. ( Kriyantono, 2006).

Sehingga penulis memilih key informan berdasarkan karakteristik yang dianggap memiliki informasi yang relevan dengan perumusan masalah penelitian ini. Key informan dalam penelitian ini adalah seorang Brand Manager atau yang sering kita kenal sebagai pimpinan cabang PT.

Jalur Nugraha Ekakurir ( JNE) cabang Lampung, agen dan marketing PT. Jalur Nugraha Ekakurir ( JNE ) cabang Lampung. Lalu Informan dalam penelitian ini adalah konsumen atau para pengguna jasa titipan kilat di PT. Jalur Nugraha Ekakurir ( JNE ).

\subsection{Teknik Analisis Data}

Dalam penelitian ini teknik analisis data yang penulis lakukan adalah teknik komparatif konstan ( Miles dan Huberman, 1994 ), yaitu :

1. Menempatkan data kedalam kategori-kategori yang kemudian kategori tersebut harus dapat diperbandingkan satu dengan yang lainnya.

2. Memperluas kategori tersebut sehingga tidak terjadi tumpang tindih antar kategori.

3. Menyederhanakan dan mengintegrasikan data kedalam struktur teoretid yang koheren ( masuk akal, saling bertalian secara logis ). Dengan demikian penulis mengkategorikan data menjadi kategori sesuai dengan konsep strategi pemasaran jasa dari PT. Jalur Nugraha Ekakurir ( JNE ) 
cabang Lampung serta volume pemakaian jasa titipan kilat, yang kemudian diproses sesuai dengan tahap-tahap diatas.

\subsection{Uji Keabsahan Data}

Pemeriksaan keabsahan data sangat diperlukan adalah penelitian kualitatif demi kesahan dan kehandalan serta tingkat kepercayaan data yang terkumpul. Validitas dan reabilitas data perlu diuji melalui teknik keabsahan data teknik menguji dan memastikan temuan pemeriksaan kepresentatifan yakni aspek pilihan informan yang mewakili masalah yang diteliti, memeriksa pengaruh penelitian, memberi bobot pada bukti, membuat perbandingan atau pertentangan, membuat replika temuan, mencari penjelasan tandingan,serta teknik terakhir adalah mendapatkan umpan balik dari key informan dan informan.

Teknik umum pengujian keabsahan data dilakukan dengan menggunakan teknik triangulasi. Triangulasi adalah kombinasi beberapa sudutpandang yang sering digunakan meliputi empat hal pokok yakni, triangulasi data, triangulasi peneliti, triangulasi teori, dan triangulasi metodologi ( Daymon, 2008 ).

Melalui teknik pemeriksaan ini, penulis menggunakan teknik triangulasi data dan triangulasi teori, di mana data di kumpulkanserta dikaitkan dengan teoriteori dari terlaksananya seluruh kegiatan strategi pemasaran oroduk jasa titipan kilat dari PT. JALUR NUGRAHA EKAKURIR cabang Lampng tersebut, diyakini fakta, data, dan informasi yang di dapat dapat di pertanggung jawabkan dan memenuhi persyaratan, keshahihan dan keandalan.

Pemeriksaan dan pengecekan dilakukan peneliti pada penelitian ini melalui sumber lain yaitu dengan cara membandingkan data hasil pengamatan dan hasil wawancara dngan key informan. Ini juga termasuk dokumen yang berkaitan dengan studi literatur melalui data sekunder yang diperoleh..

\section{ANALISIS DAN PEMBAHASAN}

\subsection{Gambaran Umum PT Tiki Jalur Nugraha Ekakurir (JNE) Cabang Lampung}

Pada awalnya PT Tiki Jalur Nugraha Ekakurir (JNE) didirikan oleh Bapak H. Soeprapto Suparno, pada tahun 1990. PT TIKI Jalur Nugraha Ekakurir memulai kegiatan usahanya yang berpusat pada kegiatan kepabean atau impor kirim barang/dokumen serta pengantarannya dari luar negeri ke Indonesia. Lingkup bisnis yang dijalani PT TIKI JNE adalah pengiriman (courier), penyimpanan dan pendistribusian (logistic and distribution), transportasi (moving, trucking, air sea cargo), kepabean (costum clearance), penjemputan bandara (escort service), pengiriman uang (money transfer). PT TIKI JNE berpusat di Jakarta dengan memiliki kantor cabang di kota-kota besar di Indonesia antara lain Bandung, Yogyakarta, Solo, Semarang, Batam, Medan, Palembang, Balikpapan, Banjarmasin, Surabaya, Pontianak, Kendari, Makasar, Denpasar dan termasuk Kota Bandar Lampung serta kota-kota lainnya. Selain itu PT TIKI JNE memiliki lebih dari 36 agen utama dan 500 gerai (counter) yang tersebar luas di Indonesia serta didukung lebih 12.000 karyawan dan 300 kendaraan sebagai sarana operasional, JNE dengan kinerjanya yang teritegrasi dengan efektif, efisien dan feksibel ingin memberikan kualitas pelayanan terbaiknya demi terciptanya kepuasan konsumen.

Kecepatan dan kehandalan layanan yang konsisten dan bertanggung jawab membuat kredibilitas JNE semakin tinggi di mata pelanggan maupun mitra kerja. 
Kemudian seiring dengan peningkatan investasi asing, pertumbuhan ekonomi dalam negeri, dan perkembangan teknologi informasi, serta beragam inovasi produk yang dikembangkan, kinerja JNE semakin tumbuh juga berkembang di kalangan dunia usaha maupun masyarakat Indonesia.

Peluang yang terus tumbuh ini mendorong JNE untuk terus memperluas jaringannya ke seluruh kota besar di Indonesia. Saat ini titik-titik layanan JNE telah mencapai diatas 1.000 lokasi dan lebih dari 250 lokasi JNE telah terhubungkan dengan sistem komunikasi on-line, dikawal oleh sistem dan akses situs informasi yang efektif serta efisien bagi konsumen dalam upaya mengetahui status terkini pengiriman paket atau dokumen. TIKI JNE mengedepankan sumber daya manusia sekaligus teknologi sebagai bagian dari pengembangan. Dari mesin X-Ray, GPS, hingga alat komunikasi satelit. Kehandalan dan komitmen JNE ini terbukti dengan diraihnya berbagai bentuk penghargaan serta sertifikasi ISO 9001:2008 atas sistem manajemen mutu.

Visi, Misi dan Nilai-nilai Dasar PT

Tiki Jalur Nugraha Ekakurir (JNE) adalah sebagai berikut :

\section{Visi:}

Untuk menjadi perusahaan rantai pasok global terdepan di dunia

Misi:

Untuk memberi pengalaman terbaik kepada pelanggan secara konsisten.

\section{Nilai-nilai Dasar :}

1. Jujur

2. Disiplin

3. Tanggung Jawab

4. Visioner

Pada dasarnya setiap perusahaan dibentuk atas dasar tujuan tertentu. Untuk dapat mencapai tujuan tersebut maka perlu dibentuk suatu organisasi agar tujuan yang telah ditentukan tersebut dapat menyusun organisasi yang terdiri atas orang-orang yang cakap dan memiliki dedikasi tinggi dalam melaksanakan tugas dan kewajibannya. Struktur organisasi TIKI JNE menunjukkan penjelasan wewenang dan pengaturan tanggungjawab organisasi perusahaan untuk menunjang segala aktivitas perusahaan agar tercipta keserasian antar elemen yang ada dalam perusahaan.

PT Tiki Jalur Nugraha Ekakurir (JNE) Cabang Lampung dipimpin oleh seorang Kepala Cabang yang dibantu oleh beberapa bagian sebagaimana berikut :

1) Kepala Cabang

a. Memimpin perusahaan cabang dan karyawan.

b. Bertanggungjawab atas operasional perusahaan dalam menyelesaikan dan melaksanakan tugas seharihari.

c. Menjabarkan program kerja.

d. Memperhatikan perkembangan pasar.

2) Bagian Pemasaran

a. Mencari pelanggan atau pengguna jasa.

b. Memperkenalkan fasilitas-fasilitas perusahaan yang ada.

c. Mengurusi keluar masuknya barang.

3) Bagian Personalia

a. Mengurusi perekrutan karyawan atas ijin Direktur.

b. Mengurusi mengenai data-data karyawan.

c. Memberikan gaji bagi karyawan.

d. Mengurusi karyawan yang mengajukan pinjaman uang.

4) Bagian Administrasi

a. Mengklasifikasi surat jalan yang telah disepakati penerima barang.

b. Mengarsipkan permohonan faktur surat jalan dengan pengiriman barang sesuai pemberangkatan dari Cabang-cabang yang ada di wilayah Lampung. 
c. Mengurus segala sesuatu untuk memperlancar proses bongkar muat barang.

5) Bagian Keuangan

a. Memegang sirkulasi keuangan perusahaan.

b. Mengklasifikasi piutan perusahaan.

c. Memberikan instruksi ke bagian penagih untuk menagih kepada bagi yang mempunyai hutang.

6) Bagian Operasional

a. Mengecek ulang terhadap pandapatan dengan biaya operasional.

b. Mengurusi pendistribusian barang mulai dari muat sampai pada proses pembongkaran saat sampai tujuan.

c. Melaksanakan tugas-tugas lain yang diberikan oleh direktur.

7) Bagian Gudang

a. Menghitung setiap jumlah barang yang masuk.

b. Mengemas atau mengepak barang yang akan dikirim sepraktis dan serapi mungkin agar aman saat di armada.

c. Melaksanakan tugas-tugas lain yang diberikan oleh Direktur.

8) Bagian Administrasi Pajak dan Statistik

a. Berwenang untuk menjamin kelancaran operasional armada yang digunakan.

b. Mengurusi setiap pembayaran pajak.

9) Bagian Kurir

a. Mengantarkan barang sampai ke tempat penerima.

b. Melakukan bongkar muat barang masuk atau datang.

10) Bagian Penagihan

a. Menerima instruksi dari bagian keuangan mengenai piutang yang telah jatuh tempo

b. Melaksanakan tugas-tugas lain yang diberikan oleh Direktur.
Kemudian dalam memberikan pelayanan kepada konsumennya, PT TIKI JNE menjalankan proses manajemen pemasaran melalui tahapan sebagai berikut

1. Menilai Peluang Pasar

TIKI JNE sadar bahwa terdapat banyak perusahaan sejenis yang ada di Indonesia. Tapi JNE yakin, mereka memiliki benefit-benefit yang lebih baik yang mampu ditawarkan kepada konsumennya. PT TIKI JNE masih merasa yakin bahwa pangsa pasar untuk perusahaan ini masih cukup bagus, tinggal bagaimana menarik konsumen yang ada agar menggunkan jasa perusahaan ini.

TIKI JNE sadar bahwa kebutuhan untuk jasa pengiriman masihlah tinggi, apalagi calon konsumen mencari suatu perusahaan pengiriman yang mampu memberikan pelayanan terbaik, tentunya dengan harga yang murah. Apalagi kebanyakan konsumen JNE adalah perusahaan-perusahaan yang biasanya biaya pengiriman ini akan mempengaruhi terhadap biaya produksi mereka sehingga mereka mencari perusahaan yang berkualitas tetapi biayanya murah.

2. Merumuskan strategi pemasaran

Setelah melihat peluang pasar yang dimiliki maka JNE merumuskan strategi pemasaran dengan melihat kelebihan, kelemahan, ancaman dan peluang. Dalam merumuskan strategi pemasaran ini seorang manajer pemasaran harus memiliki tujuan yang spesifik dan konsisten.

TIKI JNE merumuskan strategi yang menonjolkan akan kelebihan-kelebihan yang dimiliki perusahaan untuk menarik perhatian konsumen. Misalnya mereka memanfaatkan IT dalam kegiatan operasionalnya sehingga akan menarik perhatian konsumen. Apalagi 
di tengah-tengah persaingan yang ketat jadi perumusan strategi pemasaran disini sangatlah penting. Selain itu pemanfaatan IT dirasa sangatlah efisien karena dapat memperingan pekerjaan karyawan. Dan ini adalah peluang bagi JNE untuk terus mempertahankan eksistensinya karena penggunaan IT ini menjadi barometer bagi perusahaanperusahaan pesaing.

3. Menerapkan strategi tersebut

Setelah strategi dirumuskan maka strategi tersebut akan dilaksanakan. Disini diperlukan kontrol atau pengendalian untuk menjaga bahwa strategi tersebut dapat dilakukan sesuai dengan yang diharapkan. Dan pengendaian ini memberikan umpan balik kepada manajer dan menjadi dasar untuk analisis peluang pasar dalam periode perencanaan berikutnya.

4. Memiliki program-program khuusus untuk mensukseskan strategi

Untuk mendukung penerapan strategi tersebut, TIKI JNE juga memiliki program-program khusus. Programprogram ini ditujukan untuk terus memberikan pelayanan terbaik kepada konsumen.

Dalam pelaksanaan strategi-strategi tersebut muncul kendala akan tetapi TIKI JNE berusaha untuk meminimalisasi kendala tersebut karena TIKI JNE ingin sukses dalam bisnis ini. Cara untuk meraih sukses dalam bisnis jasa yang dilakukan oleh TIKI JNE adalah:

1. Memperbaharui jasa yang ditawarkan

JNE selalu berusaha melakukan inovasi-inovasi dalam pemberian jasa kepada konsumen. Kemudian ekspansi jasa yang dilakukan oleh JNE ini menunjukkan bahwa perusahaan ini terus berupaya untuk meningkatkan pelayanan demi memenuhi kebutuhan konsumen.

2. Melokalisasi system point of service
TIKI JNE memiliki kantor/cabang hampir di seluruh daerah di Indonesia untuk mempermudah jangkauan para konsumen yang tidak hanya ada di kota-kota besar namun juga banyak yang terdapat di daerah-daerah terpencil. TIKI JNE meningkatkan kemampuan dalam menyediakan jasa yang dimilikinya sehingga konsumen mempunyai berbagai piihan terutama piihan lokasi penyedia jasa tersebut agar memudahkan konsumen untuk mendapatkanya dan sebagai bentuk peningkatan dari kualitas jasa.

3. Mengadakan kontrak layanan terhadap konsumen

TIKI JNE mempunyai cara sendiri untuk mempertahankan pelanggannya yaitu dengan memberikan harga khusus atau diskon yang diberikan untuk para pelanggan tetapnya. Hal ini dilakukan sebagai wujud terima kasih karena telah percaya pada TIKI JNE dan untuk menjaga agar para konsumen tersebut tidak lari ke perusahaan lain.

4. Mengunakan Teknologi Informasi

Bisnis jasa harus memanfaatkan IT agar dapat meningkatkan kualitas jasa dan pelayanan yang diberikan, selain itu untuk membedakan dengan pesaing atau kompetitor. JNE menggunkan system on-line dalam kegiatan operasionalnya, yaitu dengan sistem ORION. Dengan sistem ini konsumen dapat mengetahui keberadaan barangnya hanya dalam hitungan detik.

5. Menilai strategis jasa pada konsumen Strategi yang dilakukan oleh JNE adalah untuk memuaskan kebutuhan konsumen. Dengan mempelajari keinginan dan kebutuhan konsumen saat ini dan meramalkan kebutuhan konsumen dimasa yang akan datang.

Dalam menjalankan usahanya TIKI JNE setelah mengetahui kendala-kendala yang muncul dan kemudian menemukan 
solusinya sebagai upaya meningkatkan kinerjanya. Salah satu hal nyata yang mereka lakukan adalah mempertahankan pelanggan dan menarik konsumen baru dengan memberikan kepuasan pelayanan kepada mereka. Di sini para konsumenlah yang menilai kualitas pelayanan yang diberikan JNE.

\subsection{Analisis dan Pembahasan}

Ada 5 dimensi kualitas pelayanan yang dapat dilihat konsumen di JNE yaitu dimensi bukti fisik (tangible), dimensi kehandalan (reliability), dimensi daya tanggap (responsivenees), dimensi jaminan (assurance) dan dimensi empati (emphaty). Kelima dimensi kualitas pelayanan tersebut dilakukan guna memenuhi ekspektasi konsumen yaitu konsumen merasakan kepuasan terhadap layanan jasa pengiriman yang diberikan oleh PT TIKI JNE.

Adapun implementasi strategi pemasaran PT. TIKI JNE sebagai bentuk pelayanan yaitu dilakukan melalui strategi bauran pemasaran jasa yang dilakukan oleh dalam rangka menjamin kepuasan pelanggan adalah sebagai berikut :

1. Bukti Fisik (Tangible)

Merupakan aspek-aspek nyata dapat dilihat dan diraba, unsur ini meliputi penampilan fasilitas fisik dan produkproduk layanan pada PT TIKI JNE. PT TIKI JNE mengembangkan produknya di tingkatan tambahan (augmented product) dalam strategi pemasarannya. Adapun penjelasan mengenai tingkatan dari layanan JNE sebagai berikut:

Product Level:

1. Core benefit: jasa pengiriman.

2. Basic Product: jasa pengiriman barang dengan berat di atas 500 gram

3. Expected Product: diterimanya barang di tujuan

4. Augmented Product: melayani pesanan dan pengiriman makanan khas daerah ke tujuan
5. Potential: jasa pengambilan barang dari asal dan mengirimkan barang tanpa ada batasan berat dan jenis makanan sampai ke tujuan.

TIKI JNE memberikan nilai tambah (added value) dibandingkan pesaingnya dengan membuat layanan yang diharapkan dan memberi kemudahan bagi konsumen, yaitu konsumen dapat menikmati makanan daerah yang disukainya.

Bukti fisik juga meliputi penampilan fasilitas fisik seperti gedung dan ruangan pendukung jasa, tersedianya tempat parkir, kebersihan, kerapian, dan kenyamanan ruangan, kelengkapan peralatan komunikasi, dan penampilan karyawan. Ruangan yang bersih dan rapi, serta penampilan setiap karyawan pada perusahaan TIKI JNE yang baik menjadi keunggulan tersendiri. Setiap barang yang ingin dikirim oleh pelanggan telah di pilahpilah sesuai daerah yang akan dikirim.

Produk jasa TIKI JNE berupa pelayanan, di mana lingkup bisnis JNE adalah memadukan kebutuhan masyarakat akan komunikasi yang peka waktu, akurat, dan aman dalam suatu sistem layanan yang terintegrasi secara efektif, efisien, dan fleksibel. Adapn jenis layanan TIKI JNE, yaitu :

a. Pengiriman (Courier)

1. Layanan Kurir Dalam Kota (Intra City)

Merupakan layanan penjemputan dan pengiriman yang diberikan kepada konsumen dengan lingkup hanya dalam kota saja. Jenis layanan yang diberikan adalah :

a. Biasa (Reguler), adalah pengantaran dalam waktu 2-5 hari.

b. Penting (urgent), adalah pengantaran 1 hari

c. Sangat penting (Top Urgent), adalah pengantaran dalam hari yang sama. 
2. Layanan Kurir Dalam Negeri (Domestic Courier)

Merupakan layanan penjemputan dan pengiriman yang diberikan kepada konsumen dengan lingkup ke seluruh wilayah Indonesia. Jenis layanan yang diberikan adalah :

a. OKE (Ongkos Kirim Ekonomis)

b. Express Reguler (Kilat Biasa)

c. YES (Yakin Esok Sampai)

d. SS ( Special Service)

e. Hand Carry (Layanan Diplomat)

b. Layanan Kargo Laut dan Udara (Sea and Air Cargo Service)

Merupakan layanan pengiriman kargo yang diberikan kepada konsumen dengan lingkup pengantaran ke seluruh wilayah Indonesia dengan mengunakan sarana ekspedisi laut dan udara.

3. Jasa Perpindahan Dan Angkutan Darat (Moving and Trucking)

Merupakan layanan perpindahan dan pengepakan barang seluruh isi rumah, kantor, pabrik atau galeri dan memindahkannya ke lokasi baru serta membuka pengepakan dimana sebelumnya diadakan kunjungan terlebih dahulu untuk mendiskusikan pengemasan, pengepakan dan pengaturan transportasi angkutan yang tepat sampai ke tempat tujuan.

4. Logistik dan Disrtibusi (Logistic and Distribution)

Merupakan jenis layanan yang terintegras antara pergudangan (warehouse), pencatatan (inventory), dan sekaligus pegantarannya (distribution).

5. Jasa layanan Kepabeanan (Customs Clearance)

Merupakan layanan yang diberikan kepada konsumen guna mengantisipasi dan menghindari keterlambatan dalan proses pengurusan kepabeanan sehingga konsumen bisa mendapatkan kirimannya tepat pada waktunya.

6. Jasa Penjemputan Bandara ( Airport Escort)

Merupakan layanan yang diberikan kepada kondumen yang bertujuan untk menjamin kelancaran proses kedatangan, transit atau keberangkatan para konsumen. Dalam pelayanan ini, TIKI JNE menyediakan jasa pendamping melalui proses imigrasi dan kepabeanan, mengatur transportasi, penginapan, serta reservasi tiket. Hal ini membantu konsumen menghindari keterlambatan dan antrian yang tidak perlu.

7. Jasa Pengiriman Uang (Money Transfering)

Mulai Oktober 2006, TIKI JNE bekerjasama dengan suatu badan usaha yang bergerak dalam bidang pengiriman uang yaitu Western Union. Sekarang Western Union sudah dapat melayani permintaan konsumen tersebut walaupun pelayanannya masih sangat terbatas, baru beberapa counter saja. TIKI JNE terus berusaha memperbanyak counter-counternya dengan memanfaatkan seluruh jaringan kerja JNE.

2. Kehandalan (Reliability)

Kehandalan merupakan kemampuan perusahaan untuk memberikan pelayanan sesuai yang dijanjikan secara akurat dan terpercaya. Kinerja harus sesuai dengan harapan pelanggan yang berarti ketepatan waktu, pelayanan yang sama untuk semua pelanggan tanpa kesalahan, sikap yang simpatik, dan dengan akurasi yang tinggi.

PT TIKI JNE selalu berusaha memberikan yang terbaik agar pelanggan puas dengan pelayanan yang 
ada. Berkat manajemen yang baik itulah perusahaan ini semakin lancar dan mempunyai banyak pelanggan. Perusahaan menyediakan fasilitasfasilitas bagi pemakai jasa diantaranya kualitas armada yang mampu mengirim barang sampai tujuan tepat waktu, prosedur pembayaran yang mudah tidak berbelit-belit seandainya terjadi suatu hal yang merugikan pengguna jasa ini pada proses operasional. Dari hal tersebut perusahaan mendapat simpati dan kepercayaan dari pelanggan atau pengguna jasa paket barang dan dikumen sehingga secara tidak langsung membantu proses pemasaran dan mudah dikenal di khalayak pengguna transportasi.

Kehandalan jasa yang ditawarkan oleh PT TIKI JNE berkaitan dengan kecepatan proses administrasi pelayanan, penyerahan kiriman yang cepat dan tepat waktu serta tepat pada orang yang menerimanya. Di samping itu tarif pengiriman sesuai dengan kualitas layanan yang diberikan.

Kehandalan jasa layanan TIKI JNE juga dibuktikan dengan kemampuan dalam menjangkau seluruh wilayah di dalam negeri dan beberapa negaranegara di luar negeri di mana TIKI JNE memberlakukan minimum charge untuk setiap pengiriman adalah $1 \mathrm{Kg}$ meskipun secara aktual berat barang kurang dari $1 \mathrm{Kg}$. Untuk pengiriman dengan kemasan besar namun ringan, akan diberlakukan penentuan biaya dengan rumus M3 (perhitungan volume kubikasi untuk mendapatkan nilai $\mathrm{Kg}$ dengan rumus).

3. Daya Tanggap (Responsivenees)

Maksud dari daya tanggap adalah kemauan untuk membantu dan memberian pelayanan yang cepat (responsif) dan tepat kepada pelanggan, dengan penyampaian informasi yang jelas.

Process (proses pelayanan) merupakan prosedur atau pemroduksian jasa tersebut, yang biasanya terdapat tahapan-tahapan mulai dari awal pembelian jasa sampai terjadinya kepuasan atau kekecewaan pelanggan. Hal ini sangat perlu di perhatikan karena menyangkut kualitas layanan sebuah perusahaan jasa.

Berkaitan dengan daya tanggap yang diberikan oleh PT TIKI JNE dalam memberikan pelayanan kepada konsumennya dimana staf petugas yang melayani memiliki keterampilan dalam menanggapi kebutuhan pelanggan, kemudian kesediaan petugas memberikan saran dan petunjuk kepada pelanggan dalam menggunakan jasa layanan pengiriman yang diberikan serta senantiasa menanggapi keluhan pelanggan baik keluhan secara langsung maupun melalui telepon, SMS maupun internet.

Di samping itu PT TIKI JNE memberikan standar pelayanan berupa keramahan karyawan, ketelitian dalam penginputan barang dan alamat yang ingin dituju. Bahkan ada sebuah fitur layanan untuk pelanggan yang ingin ikut memonitor proses pengiriman barangnya melalui website resmi PT TIKI JNE tersebut. Jadi pelanggan akan akan tahu barangnya sudah sampai di mana atau sudah sampai pada tujuannya.

4. Jaminan (Assurance)

Aspek yang penting lainnya dari kebutuhan masyarakat terhadap kualitas layanan jasa pengiriman surat dan paket yang diselenggarakan TIKI JNE adalah Assurance atau jaminan bagi pelanggannya.

Jaminan yang diberikan oleh PT TIKI JNE dalam pengiriman barang adalah 
berupa keamanan pengiriman

dokumen. Dan juga jaminan penggantian atas kerugian jika terjadi kerusakan/kehilangan kiriman dokumen akibat kesalahan selama dalam pengiriman. Semakin meningkatnya konsumen yang menggunakan jasa PT TIKI JNE menbuktikan bahwa konsumen percaya akan kualiatas layanan yang diberikan oleh PT TIKI JNE.

5. Empati (Emphaty)

Empati maksudnya adalah memberikan perhatian yang tulus dan bersifat individual atau pribadi yang diberikan kepada para pelanggan dengan berupaya memahami keinginan konsumen.

Ditinjau dari pengembangan layanan jasa pengiriman yang diselenggarakan PT TIKI JNE telah memenuhi kebutuhkan masyarakat pelanggannya. Dalam hal ini, masyarakat membutuhkan petugas layanan yang dapat memberikan perhatian, tanggung jawab keamanan dan kenyamanan, serta mengutamakan kepentingan pelanggannya. Empati yang diberikan oleh staf/petugas PT TIKI JNE yang melayani konsumen adalah sikap bijaksana dan kecepatan petugas dalam memberikan informasi dan solusi atas keluhan dari pelanggan dan juga memberikan pelayanan sesuai standar dengan tidak membeda-bedakan pelanggan yang membutuhkan layanan PT TIKI JNE.

\section{KESIMPULAN DAN SARAN}

\subsection{Kesimpulan}

Berdasarkan hasil analisis dan pembahasan dapat disimpulkan beberapa hal sebagai berikut :
1. Layanan jasa pengiriman yang diselenggarakan PT Tiki Jalur Nugraha Ekakurir Cabang Lampung pada dasarnya telah memenuhi standar kualitas sesuai dengan kebutuhan masyarakat pelanggannya berdasarkan aspek bukti fisik, kehandalan, daya tanggap, jaminan dan empati.

2. Upaya yang dilakukan oleh PT Tiki Jalur Nugraha Ekakurir Cabang Lampung guna memberikan kepuasan terhadap layanan jasa pengiriman tersebut diimplementasikan dengan cara :

a. Bukti Fisik (Tangible)

Bukti fisik meliputi penampilan fasilitas fisik seperti gedung dan ruangan pendukung jasa, tersedianya tempat parkir, kebersihan, kerapian, dan kenyamanan ruangan, kelengkapan peralatan komunikasi, dan penampilan karyawan. Ruangan yang bersih dan rapi, serta penampilan setiap karyawan pada perusahaan TIKI JNE yang baik menjadi keunggulan tersendiri.

b. Kehandalan (Reliability)

Kehandalan merupakan kemampuan perusahaan untuk memberikan pelayanan sesuai yang dijanjikan secara akurat dan terpercaya. PT TIKI JNE selalu berusaha memberikan yang terbaik agar pelanggan puas dengan pelayanan yang ada. Kehandalan jasa yang ditawarkan oleh PT TIKI JNE berkaitan dengan kecepatan proses administrasi pelayanan, penyerahan kiriman yang cepat dan tepat waktu serta tepat pada orang yang menerimanya. Di samping itu tarif pengiriman sesuai dengan kualitas layanan yang diberikan. Kehandalan jasa layanan TIKI JNE juga 
dibuktikan dengan kemampuan dalam menjangkau seluruh wilayah di dalam negeri dan beberapa negara-negara di luar negeri di mana TIKI JNE memberlakukan minimum charge untuk setiap pengiriman.

c. Daya Tanggap (Responsivenees)

PT TIKI JNE dalam memberikan pelayanan kepada konsumennya dimana staf petugas yang melayani memiliki keterampilan dalam menanggapi kebutuhan pelanggan, kemudian kesediaan petugas memberikan saran dan petunjuk kepada pelanggan dalam menggunakan jasa layanan pengiriman yang diberikan serta senantiasa menanggapi keluhan pelanggan baik keluhan secara langsung maupun melalui telepon, SMS maupun internet. Di samping itu PT TIKI JNE memberikan standar pelayanan berupa keramahan karyawan dan ketelitian dalam penginputan barang dan alamat yang ingin dituju. Bahkan ada sebuah fitur layanan untuk pelanggan yang ingin ikut memonitor proses pengiriman barangnya melalui website resmi PT TIKI JNE tersebut. Jadi pelanggan akan akan tahu barangnya sudah sampai di mana atau sudah sampai pada tujuannya.

d. Jaminan (Assurance)

Jaminan yang diberikan oleh PT TIKI JNE dalam pengiriman barang adalah berupa keamanan pengiriman dokumen. Dan juga jaminan penggantian atas kerugian jika terjadi kerusakan/kehilangan kiriman dokumen akibat kesalahan selama dalam pengiriman. Semakin meningkatnya konsumen yang menggunakan jasa PT TIKI JNE menbuktikan bahwa konsumen percaya akan kualiatas layanan yang diberikan oleh PT TIKI JNE.

e. Empati (Emphaty)

Empati yang diberikan oleh staf/petugas PT TIKI JNE yang melayani konsumen adalah sikap bijaksana dan kecepatan petugas dalam memberikan informasi dan solusi atas keluhan dari pelanggan dan juga memberikan pelayanan sesuai standar dengan tidak membeda-bedakan pelanggan yang membutuhkan layanan PT TIKI JNE.

\subsection{Saran}

Saran-saran yang dapat dikemukakan sebagai alternatif perbaikan bagi PT Tiki Jalur Nugraha Ekakurir Cabang Lampung adalah sebagai berikut :

1. Untuk mempertahankan penilaian baik masyarakat yang membutuhkan layanan jasa pengiriman, maka yang dilakukan PT Tiki Jalur Nugraha Ekakurir Cabang Lampung adalah, tetap mempertahan standar kualitas layanan (Service quality) atau jaminan mutu kepada pelanggan sebagai acuan dalam pengembangan berbagai layanannya secara inovatif.

2. PT Tiki Jalur Nugraha Ekakurir Cabang Lampung harus tetap meningkatkan brand image perusahaan, sehingga mampu bersaing secara kompetitif dengan penyelenggara layanan jasa pengiriman lainnya.

\section{DAFTAR PUSTAKA}

Pandji Anoraga, SE.,M.M . 1997. Manajemen Bisnis. Jakarta: PT . Rineka Cipta. 
Dr.Etta Mamang Sangadji, M.Si \& Dr.

Sopiah,MM., M.Pd. Prilaku

Konsumen. Penerbit Andi.

www. Academia. Edu / 16644498 /

Pemasaran Jasa www.landasan

teori.com /Pemasaran

Lupiyoadi, Hamdani. 2006. Manajemen

Pemasaran Jasa, Edisi Kedua.

Jakarta : Penerbit Salemba Empat.

Umar, 2003. Pengukuran Tingkat Kepuasan

Pelanggan. Jakarta : Gramedia

Pustaka Utama.

Tjiptono, Fandi. 2005. Pemasaran Jasa. Malang : Bayumedia.

Akdon, Riduwan. 2006. Rumus dan Data dalam Aplikasi Statistika. Cetakan I. Bandung : Alfabeta.

Ali, Hasan. 2008. Marketing. Jakarta : PT. Buku Kita.

Alma, Buchari. 2007. Manajemen Pemasaran dan Pemasaran Jasa. Edisi

Revisi. Bandung : Alfabeta.

Kotler, Philip. 2005. Manajamen Pemasaran, Jilid 1 dan 2. Jakarta: PT.Indeks

Kelompok Gramedia.

Irawan, Handi. 2002. 10 Prinsip Kepuasan Pelanggan. Jakarta: PT. Elex Media Komputindo Kelompok Gramedia. 